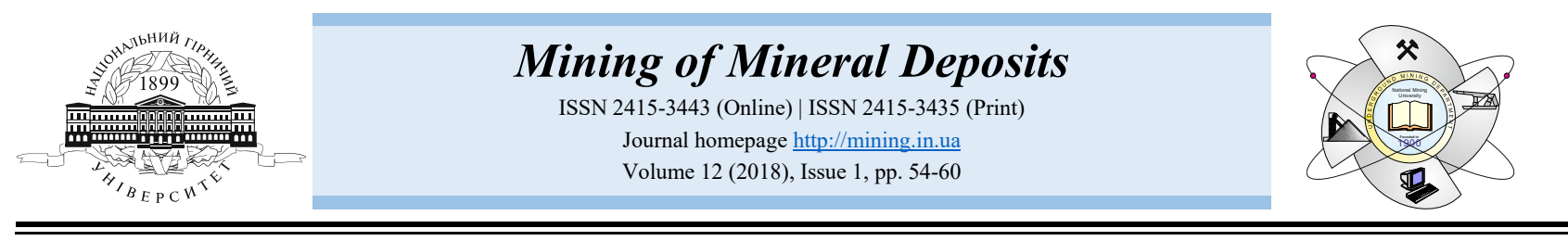

UDC 622.235

https://doi.org/10.15407/mining12.01.054

\title{
INTENSIFICATION OF TECHNOLOGICAL PROCESSES IN DRILLING AND BLASTING OPERATIONS DURING OPEN-CUT MINING IN KYZYLKUM REGION
}

\author{
Sh. Zairov ${ }^{1}$, M. Ravshanova ${ }^{1 *}$, Sh. Karimov ${ }^{1}$ \\ ${ }^{1}$ Navoiy State Mining Institute, Navoiy, Uzbekistan \\ *Corresponding author: e-mail m_ravshanova@mail.ru, tel.+998933141054
}

\begin{abstract}
Purpose. It is found that for long term standing, the pit bench profile is close to the boundary of the disturbed zone. Therefore, long stability of the bench can be estimated in respect to the size of the disturbed area and the boundary of residual deformations zone.

Methods. Protective ability of the shielding splitting during the perimeter blasting in Kyzylkum quarries is estimated by the amplitude coefficient depending on the width of the shielding splitting, duration of explosive pulse as well as physical and mechanical properties of the shielding splitting filler.

Findings. Analysis of the research regarding special methods of conducting drilling and blasting operations (DBO) for bench slope development showed that the most effective way of reducing deformation zone beyond the designed surface of separation is to use pre-splitting. Analysis of the research related to selecting parameters of contouring charges for creating a shielding splitting revealed the absence of methods which can reasonably and unequivocally recommend DBO parameters for specific mining and geological conditions. Currently known dependences only approximately allow to estimate the relationships between the main parameters of contouring explosives.

Originality. In accordance with the "Research method of blast impact of contouring charges in the border zone of the quarry", experiential and industrial tests of the developed blast design and effective parameters of perimeter blasting have been conducted in Muruntau quarry. As a result, stable slopes of 20-meter benches with the slope angle 60 degrees were formed, eliminating the need for additional wall cutback, simultaneously improving labour safety at lower horizons. The developed effective parameters of perimeter blasting ensured creation of maximal widest shielding splitting for the designed limit of the disturbance zone thickness with destroyed inter-block connections in the area adjacent to the slope.

Practical implications. Fixing mixture underwent industrial testing and was implemented in Tashkura quarry of Djeroy-Sardara phosphorite fields. It was established that during explosive fragmentation of rock mass, using stemming of fixing mixture, the amount of dust and gas clouds is reduced by $30-35 \%$ as compared with stems made of drill cuttings.
\end{abstract}

Keywords: open cut mining, boundary zone, drilling, geological conditions, blasting

\section{INTRODUCTION}

About $50 \%$ of all the gold mines of the world recently put into operation implement open cut mining. At the same time, if pits depth reaches $15 \mathrm{~m}$, the efficiency of open-cast mining decreases by $5-15 \%$. The current stage of open cut mining development is characterized by operations at great depths. Increasing depth of pits leads to increased amount of overburden. This fact dramatically aggravates economic problems of mining deposits, which are particularly important at the present stage of their development (Swenson, Carter, Domec, \& Delgado, 2011; Abdul-Wahab \& Marikar, 2012; Dougherty, 2013).

Traditional technology of DBO (drilling and blasting operations) in deep horizons of quarries exhausted its potential, so it is necessary to introduce more progressive methods, which will ensure the necessary quality of rock mass crushing, improvement of slope walls stability during contour blasting, using explosives with cheap components, reducing dust and gas emissions in bulk blasting, etc (Kuzu \& Ergin, 2005; Afeni \& Osasan, 2009; Gokhale, 2010; Manoj \& Monjezi, 2013).

(C) 2018. Sh. Zairov, M. Ravshanova, Sh. Karimov. Published by the National Mining University on behalf of Mining of Mineral Deposits. This is an Open Access article distributed under the terms of the Creative Commons Attribution License (http://creativecommons.org/licenses/by/4.0/), which permits unrestricted reuse, distribution, and reproduction in any medium, provided the original work is properly cited. 
Kyzylkum fields are characterized by a complex structure of ore bodies, highly variable content of useful components, steep inclinations and uneven thickness of ore bodies (Drew, Berger, \& Kurbanov, 1996; Pechenkin \& Pechenkin, 2005). Such variability significantly affects the efficiency of mining operations, considerably complicates the choice of DBO technological parameters. At the same time, with increasing production depth to the maximum economically viable values, the level of water content and fractured rocks will increase, the influence of the quarry depth on ores resistance to explosive destruction will rise, and so will the requirements for walls preservation. As a result, scientific research, development and implementation of methods for intensifying DBO in Kyzylkum quarries allow increasing efficient use of blasting technology, ensuring the required quality of blasted rock mass, monitoring the shape and parameters of collapse, preserving geological structure of mass and reducing preparatory and restoration works (Wilde \& Gilbert, 2000; Morelli et al., 2007; Sekisov, Shevchenko, \& Lavrov, 2016; Gasanova, 2017). All these issues are considered the cutting edge problems of science and practice of mining industry whose solution will increase economic efficiency of mines performance.

\section{THE MAIN PART OF THE ARTICLE}

Research into regularity of collapse formation during bulk blasts in open pits indicated that the problems associated with optimizing the length of the relieving wall have been explored insufficiently, and as a rule, they are utilized for granular type and simple composition of explosives, as well as initiating explosives via detonating cord. Foreign scientific literature does not dwell upon rational parameters for charges of emulsion explosives and non-electric initiation methods of blasts for creating optimal sizes of the relieving wall. The issues of rock mass geological structure preservation, reduction of preparatory and restoration operations during DBO in the open pit, increase in safety and efficiency of loading operations and transport equipment are also insufficiently described (Norov, Shemitov, Zairov, \& Tuxtashev, 2011; Norov, Nasirov, \& Zairov, 2015).

Review of the works about special methods of DBO for configuring batters showed that the most effective way of reducing deformation zone beyond the designed surface of separation is to use pre-splitting. Analysis of the research into selecting parameters of contouring charges for creating a shielding splitting revealed the absence of methods which can reasonably and unequivocally recommend drilling and blasting parameters for specific mining and geological conditions. Currently known dependences only approximately allow to estimate the relationships between the main parameters of contouring explosives.

Several wall control schemes are recommended for mining geological conditions of Muruntau field. The main shortages of these schemes are the necessity to construct and maintain transport communications in every sub bench, to increase the volume of $\mathrm{DBO}$, which leads to additional operational expenses and, consequently, increases the cost of rock mass preparation for excavation.
The effects of cylindrical and spherical explosives blast in rocks have been investigated; which allowed to determine the radius of their efficient fragmentation:

- during the blast of cylindrical explosive:

$R=\frac{R_{0} \sqrt[4]{\frac{\gamma_{e} Q}{\Delta}}}{0.476 \sqrt{v_{c v}}}, \mathrm{~m} ;$

- during the blast of spherical explosive:

$R=\frac{R_{0} \sqrt{\frac{\gamma_{e} Q}{\Delta}}}{0.625 \sqrt{v_{c v}}}, \mathrm{~m}$,

where:

$R_{0}$ - radius of the explosive, $\mathrm{m}$;

$\gamma_{e}$ - density of the explosive, $\mathrm{kg} / \mathrm{m}^{3}$;

$Q$ - energy of a weight unit, $\mathrm{kgm} / \mathrm{kg}$;

$\Delta$ - rock density in natural state, $\mathrm{kg} / \mathrm{m}^{3}$;

$v_{c v}$ - critical velocity of rock particles at the distance of radius $R, \mathrm{~m} / \mathrm{s}$.

It has been established that with decrease in the density of rocks and increase in the explosive radius, increase in the density of explosive materials and energy of the explosive weight unit, the zone of rock mass fragmentation expands during the blast of cylindrical and spherical explosives.

Using the formula of gas dynamics to determine propagation of detonation waves, discharge waves and reflected waves; taking into account the timing, we have established the distribution of splitting blast impulses for different elementary conditions and various methods of initiating. It is found that the blast of splitting explosive transmits to the environment an impulse of longer duration and lower peak pressure, which provides weaker seismic effect. It is found that during long term standing, the bench geometry is close to the boundary of the disturbed zone. Therefore, duration of the bench stability can be estimated according to the size of disturbed areas and the boundary of the residual deformations zone.

It is recommended to carry out quantitative evaluation of the effect caused by pre-splitting in Kyzylkum quarries using the coefficient of contour blasting efficiency:

$$
k_{e f}=\left(K_{a}\left(V_{v}-V_{c r}\right)\right) \cdot\left(V_{v}-V_{c r} \cdot K_{a}\right)^{-1} \text {, }
$$

where:

$K_{a}-$ shielding amplitude factor;

$V_{v}$ - mass velocity of the shear behind the front of the stress wave coming to the shield, $\mathrm{m} / \mathrm{s}$;

$V_{c r}$ - critical value of mass velocity of the shear behind the front of the stress wave, $\mathrm{m} / \mathrm{s}$.

Protective capacity of the shielding splitting during perimeter blasting in Kyzylkum quarries is estimated by means of amplitude ratio that depends on the width of shielding splitting, duration of explosive impulse and physical and mechanical properties of the shielding splitting filler: 
$K_{a}=\left(\left(\left(\frac{\pi l_{s h} \rho V_{r}}{2 t \gamma_{f} V_{f}^{2}}\right)^{2}+1\right) \cdot\left(1-\left(1-E_{1} E_{2}^{-1}\right) l_{s h}\right)^{-1}\right)^{0.5}$,

where:

$l_{s h}-$ width of the shielding splitting, $\mathrm{m}$;

$\rho$ - density of rocks, $\mathrm{kg} / \mathrm{m}^{3}$;

$V_{r}$ - velocity of longitudinal waves propagation in the rock, $\mathrm{m} / \mathrm{s}$;

$t$ - time of a positive phase of stress wave existence, $\mathrm{s}$;
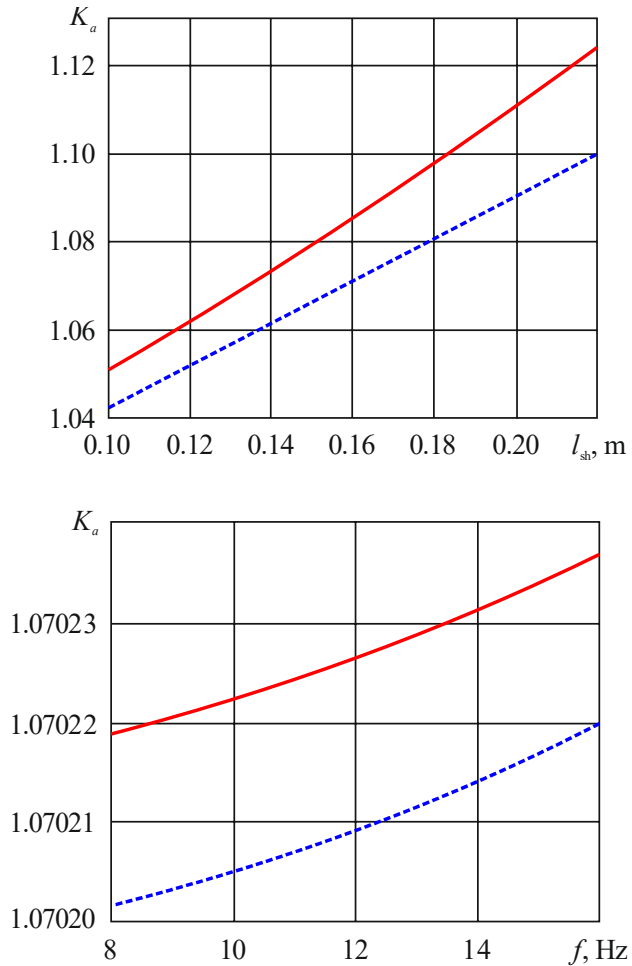

$\gamma_{f}-$ density of the splitting cavity filler, $\mathrm{kg} / \mathrm{m}^{3}$;

$V_{f}$ - velocity of longitudinal waves propagation in the filler of the splitting cavity, $\mathrm{m} / \mathrm{s}$;

$E_{1}$ - deformation module on the load strand;

$E_{2}$ - deformation module of the filler on the load strand.

The research helped to establish dependences (Fig. 1) describing the change of the protective capacity coefficient of the shielding splitting in relation to its width, the density of splitting cavity filler, the frequency of blasting load, and the velocity of longitudinal waves propagation in the filler.
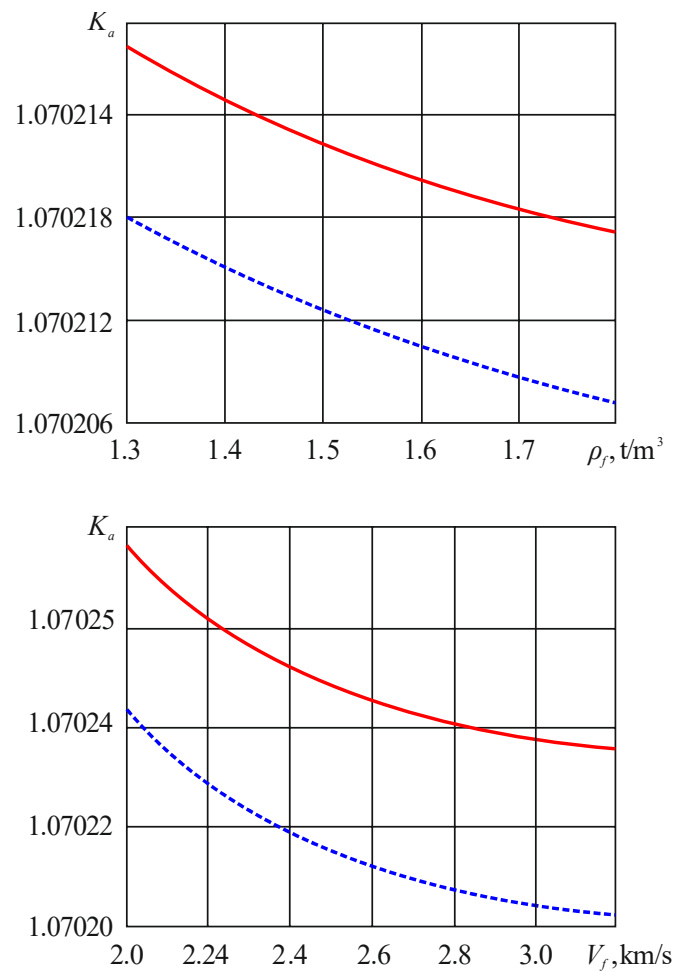

Figure 1. The dependences reflecting the change of the protective capacity coefficient of the shielding splitting (Ka) during contour blasting depending on its width $\left(l_{\text {sh }}\right)$, filler density $\left(\rho_{f}\right)$, loading frequency $(f)$, velocity of longitudinal waves propagation in the filler $\left(V_{f}\right)$, aleurolites (-), and cleaving stones (---)

The theoretical research allowed to obtain dependences for determining effective parameters of contour blasting under the condition of crack extension requirement between contouring shots. Protective ability of shielding splitting significantly depends on its cavity filler, so in calculating parameters of contouring charges, it is necessary to take into account opening of the shrink due to consolidation of the adjacent mass. Parameters of contouring charges should be selected with the view to restricting inter-block links destruction zone in accordance with the requirements for ensuring bench slope stability.

The present research resulted in the development of a mathematical model which describes the impact of the hole blast in the mass and forms the basis for determining kinematic parameters of fly-rock.

For the purpose of calculating the width of blasted rocks collapse during hole blasting with emulsion explosives, we have developed a formula which includes the main parameters determining energy characteristics of emulsion explosives, as well as physical and mechanical properties of rocks:
$L_{c}=\frac{Q_{e} \rho_{e} \pi r_{c h}^{2} l_{c h}}{f \rho g W^{3}}, \mathrm{~m}$,

where:

$Q_{e}$ - heat of emulsion explosive blast, $\mathrm{kJ} / \mathrm{kg}$;

$\rho_{e}-$ density of emulsion explosive loading, $\mathrm{kg} / \mathrm{m}^{3}$;

$r_{c h}$ - radius of emulsion explosive charge, $\mathrm{m}$;

$l_{c h}-$ height of emulsion explosive charge, $\mathrm{m}$;

$\rho$ - rock density, $\mathrm{kg} / \mathrm{m}^{3}$;

$g-$ acceleration of gravity, $\mathrm{m} / \mathrm{s}^{2}$;

$f$-coefficient of rocks hardness (Protodyakonov scale);

$W$ - line of least resistance, $\mathrm{m}$.

It is established that the width of blasted rocks collapse depends on the blast heat, density of loading, height and diameter of emulsion explosive charge, hardness and density of rocks, as well as the line of least resistance.

Another formula has been derived in order to calculate the height of blasted rocks collapse during the blast of emulsion explosives on the basis of the main factors determining parameters of the blasted block and energy concentration of emulsion explosives: 


$$
B_{c}=H_{b} \sqrt[4]{\frac{K_{E} \cdot N}{H_{b} \cdot\left(0.01-k_{a d} \sigma_{c o m} \ln d_{m}\right)}}, \mathrm{m},
$$

where:

$H_{b}$ - height of the bench, m;

$K_{E}-$ coefficient of relative energy concentration, taking into account characteristics and density of new explosive loading in the hole;

$N$ - number of blast holes rows;

$k_{a d}$ - coefficient of adaptation to the conditions of a specific quarry ( 0.0034 for Muruntau quarry and 0.0028 for Kokpatas and Daugiztau quarries);

$\sigma_{c o m}-$ threshold compressive resistance of rocks, MPa; $d_{m}$ - mean diameter of a blasted rock mass piece, $\mathrm{m}$.

It was proved that the height of blasted rocks collapse depends on the height of the bench, the number of blast holes, threshold compressive resistance of rocks, mean diameter of a blasted rock mass piece and coefficient of relative energy concentration of emulsion explosives.

It is established that fragmentation index, emulsion explosive weight and spacing are interrelated:

$K_{s}=1.22\left(\sqrt[3]{\frac{Q_{e x}}{a}}\right)^{0.73}$,

where:

$Q_{e x}$ - weight of emulsion explosive, $\mathrm{kg}$;

$a$ - spacing, $\mathrm{m}$.

In order to calculate the width of relieving wall during the blast of shot hole charges with emulsion explosive we have developed a formula which includes the main parameters determining energy characteristics of emulsion explosives, physical and mechanical properties of rocks and parameters of the blasted block:

$$
L_{r w}=0.1 W\left(\sqrt[3]{\frac{Q_{e x}}{a}}\right)^{0.73} \cdot\left(\frac{\sqrt{2 k_{e m p} q_{e} Q_{e} \mu}}{\sigma_{c o m}}-1\right), \mathrm{m},
$$

where:

$W$ - line of least resistance, $\mathrm{m}$;

$Q_{e x}$ - weight of emulsion explosive loading, kg;

$a$ - spacing, m;

$k_{\text {emp }}$ - empirical coefficient, taking into account blast energy consumption for fragmentation and displacement of the rock mass;

$q_{e}$-specific consumption of the emulsion explosive, $\mathrm{kg} / \mathrm{m}^{3}$;

$Q_{e}$ - heat of emulsion explosive blast, $\mathrm{kJ} / \mathrm{kg}$;

$\mu$ - module of the blasted rock elasticity, Pa;

$\sigma_{c o m}-$ threshold compressive resistance of rocks, MPa.

The present study revealed that the width of relieving wall changes depends on the explosive weight, blast heat, specific consumption of emulsion explosive, and the coefficient, which takes into account emulsion explosive blast energy, as well as on the module of blasted rock elasticity, threshold compressive resistance of rocks, spacing and the line of least resistance.

In order to calculate the height of relieving wall during the blast of shot hole charges with emulsion explosives we have derived a formula which includes the main factors determining physical and mechanical properties of rocks, parameters of the blasted block and the weight of emulsion explosive:

$B_{r w}=0.61 W\left(1+k_{c}\right)\left(\sqrt[3]{\frac{Q_{e x}}{a}}\right)^{0.73}, \mathrm{~m}$,

where:

$W$ - line of least resistance, $\mathrm{m}$;

$k_{c}$ - coefficient, which takes into account acoustic stiffness of blasted rocks and muck (variable in conditions of Kyzylkum fields within the range of $0.2-0.3$ );

$Q_{e x}$ - weight of emulsion explosive, kg;

$a$-spacing, $\mathrm{m}$.

The height of relieving wall changes depending on the weight of emulsion explosive, spacing, line of least resistance and the coefficient which takes into account acoustic stiffness of the blasted rock and muck.

As a result of the conducted research, specialists of Navoi Mining and Metallurgical Combinat quarries developed the composition of thermal containing substance (TCS) and the method for its production using components from local raw materials which are characterized by increased blast energy, can be safely stored and transported, and used in flooded conditions. This method implies mixing of crushed and granulated ammonium nitrate, hydrocarbon fuel and extra-activated rubber powder in the following proportion, mass, $\%$ :

- activated liquid hydrocarbon fuel $-3.5-6.5$;

- crushed ammonium nitrate - 30 ;

- activated rubber powder -2 ;

- granulated ammonium nitrate $-61.50-64.5$.

The process of producing TCS involves crushing of ammonium nitrate, its mixing with granulated ammonium nitrate, hydrocarbon fuel, rubber powder and their stirring into a homogenous mass. The additive, i.e. rubber powder, is subjected to activation by electromagnetic field with $200-1000 \mathrm{~Hz}$ frequency and electron flow density $D=4.37 \cdot 10^{17} \mathrm{el} / \mathrm{m}^{2}$ under the pressure of $40-50 \mathrm{MPa}$ and temperature $80-100^{\circ} \mathrm{C}$.

Using the above listed components in the specific ratio ensures stability of TCS and improved sensibility to the initiating impulse. Positive impact of fine rubber powder is justified by its high calorific value $(11000 \mathrm{kkal} / \mathrm{kg})$, combustion temperature $\left(1800-2100^{\circ} \mathrm{C}\right)$, and high absorption capacity. For instance, $1 \mathrm{~kg}$ of fine rubber powder absorbs up to $2 \mathrm{~kg}$ of hydrocarbon combustion liquid, while the explosive remains friable, safe and stable during storage and transportation. On the other hand, liquid hydrocarbon fuel absorbed by rubber powder stays under high pressure (up to $9.8 \cdot 10^{4} \mathrm{MPa}$ ) due to the impact of rubber elastic forces. At this pressure, the blast power will rise because of the increase in detonation velocity of combustibles. Activation of rubber powder and other components by means of high pressure, shear deformation and electromagnetic field, leads to significant release of free radicals and formation of active centers. Consequently, it results in energy growth and increase in blast power. It is commonly known that the rubber burning produces 44 percent of solid substances (hydrocarbon, hydrogen sulfide, zinc etc.), 17.7 percent of liquid combustibles and 26.2 percent of gases $\left(\mathrm{O}_{2}, \mathrm{~N}_{2}, \mathrm{CO}, \mathrm{CO}_{2}, \mathrm{H}_{2}, \mathrm{CH}_{4}\right.$, 
$\left.\mathrm{C}_{2} \mathrm{H}_{6}, \mathrm{C}_{2} \mathrm{H}_{4}, \mathrm{C}_{3} \mathrm{H}_{8}, \mathrm{C}_{3} \mathrm{H}_{6}, \mathrm{C}_{4} \mathrm{H}_{6}, \mathrm{C}_{9} \mathrm{H}_{10}\right)$. These components of TCS significantly increase the work of blast as their combustion heat reaches $50 \mathrm{MJ} / \mathrm{m}^{3}$. Used tires of cars and tractors can be turned into rubber powder. Diesel fuel, heating oil, kerosene and waste oil can be used as liquid hydrocarbon fuel.

The proposed composition and method make it possible to obtain a TCS with enhanced detonation properties, being safe for long-term storage and transportation. In addition, the proposed composition of TCS has a low production cost due to replacement of expensive aluminum powder with the rubber powder obtained by grinding waste tires.

In order to increase the retention capacity of ammonium nitrate in explosives, it is proposed to include highly dispersed additive of carbon compounds waste - soot which is separated as a waste during production of acetylene at the chemical plant JSC "Navoi Azot". Soot ensures higher velocity of detonation, greater blast power and smaller critical diameter of detonation due to good absorption capacity.

The design of shot hole charge has been developed for perimeter blasting in open mining operations, which allows to receive stable bench slopes.
With this design, blast holes are drilled by rock drilling machine SBSh-250MN according to the live grid of blasting and drilling parameters developed by the passport of this enterprise. Contouring holes are drilled by the machine Driltex-D25KS or URB-2A-2B.

The design of shot hole charging for perimeter blasting is created by the following operations: three intermediate detonators made of explosive Nobelit-216Z with diameter $70 \mathrm{~mm}$ and weight $2 \mathrm{~kg}$ each are installed in the left wall of the hole symmetrically in three places, while intermediate detonators with the same parameters are installed in the right wall of the hole in the staggered pattern, i.e. each with a radial clearance.

Fragmentation explosives and contouring charges are blasted separately in the border zone. Contouring charges are blasted with delay of $35-50 \mathrm{~ms}$. Effective parameters of contour blasting are given in Table 1 .

In accordance with the "Research method of blast impact of contouring charges in the border zone of the quarry", experiential and industrial tests of the developed blast design and effective parameters of perimeter blasting have been conducted in Muruntau quarry.

Table 1. Effective parameters of contour blasting

\begin{tabular}{|c|c|c|c|c|c|}
\hline Parameters of contour blasting & & & riants & & \\
\hline Variant & A & $\mathrm{B}$ & $\mathrm{C}$ & $\mathrm{D}$ & $\mathrm{E}$ \\
\hline Diameter of a hole, mm & 180 & 180 & 243 & 243 & 243 \\
\hline Spacing, $\mathrm{m}$ & 1.5 & 1.8 & 2.5 & 2.0 & 3.0 \\
\hline Linear weight of explosive charge, $\mathrm{kg} / \mathrm{m}$ & 1.5 & 1.7 & 2.8 & 2.6 & 3.3 \\
\hline Depth of a hole, $m$ & 23 & 23 & 23 & 23 & 23 \\
\hline Overdrilling, $\mathrm{m}$ & 3.0 & 3.0 & 3.0 & 3.0 & 3.0 \\
\hline \multicolumn{6}{|c|}{ Expected results from contour blasting } \\
\hline $\begin{array}{l}\text { Thickness of the zone disturbed by the blast of } \\
\text { contouring charge, } m\end{array}$ & 2.6 & 2.3 & 2.6 & 3.0 & 2.3 \\
\hline Amplitude coefficient of shielding & 1.7 & 1.7 & 2.2 & 2.2 & 2.2 \\
\hline $\begin{array}{l}\text { Relative reduction of the disturbed zone } \\
\text { thickness in the border zone, } m\end{array}$ & 2.0 & 2.0 & 3.7 & 3.7 & 3.6 \\
\hline $\begin{array}{l}\text { Resulting thickness of the disturbed zone } \\
\text { adjacent to the bench slope, } m\end{array}$ & 5.0 & 5.0 & 2.6 & 3.0 & 2.8 \\
\hline
\end{tabular}

As a result, stable slopes of 20-meter benches with the slope angle 60 degrees were formed, eliminating the need for additional wall cutback, simultaneously improving labour safety at lower horizons. The developed effective parameters of perimeter blasting ensured creation of maximal widest shielding splitting for the designed limit of the disturbance zone thickness with destroyed inter-block connections in the area adjacent to the slope. Implementation of recommendations on the parameters of contour blasting yielded annual economic effect of UZS $208.755 \mathrm{mln}$.

The method for reducing dust and gas emissions during bulk blasts in the quarries has been developed, comprising the industrial explosive charge and stemming of two components: inert material and fixing mixture.

A charge of industrial explosive (Nobelit 2080, ammonite No 6JV and igdanit) is placed in the hole according to the passport of drilling and blasting operations. The stemming installed above the charge consists of inert material with the height equal $1 / 2$ of total height of the stemming. Then, fixing mixture is poured over the inert stemming in the following ratio, mas $\%$ :

- solution of sodium silicate $\left(\rho=1.45-1.50 \mathrm{~g} / \mathrm{sm}^{3}\right)$ with silicate module $3.0-3.5)-30$;

- natural phosphoric anhydrite $\left(\mathrm{P}_{2} \mathrm{O}_{5} 9-10 \%\right)-20$;

- sand - 15;

- sandy loam- 15;

- water -20.

Great amounts of phosphoric anhydrite $\left(\mathrm{P}_{2} \mathrm{O}_{5} 9-10 \%\right)$, sand $\left(\mathrm{SiO}_{2}-89.24 \%, \mathrm{Na}_{2} \mathrm{O}-1.3 \%\right)$ and sandy loam $(\mathrm{NaCl}-12 \%)$ are available in the overburden rocks of Tashkura quarry of Djeroy-Sardara phosphorite deposit. Phosphoric anhydrite is used as a solidifying agent, and sandy loam is used for percolation.

The fixing mixture underwent industrial testing and was implemented in Tashkura quarry of Djeroy-Sardara phosphorite fields. It is found that during explosive fragmentation of rock mass, using stemming of fixing mixture, the amount of dust and gas clouds will be reduced by $30-35 \%$ as compared with stems made of drill cuttings. 
The study allowed to develop recommendations on blasting a block preserving geological structure of rock mass, improving useful efficiency of explosive energy impact, reducing preparatory and restoration operations during blasting on the bench, increasing safety and performance of loading and transport equipment. This is achieved by tight-face blasting using emulsion explosive with initiating system of non - electric blast according to "one hole - one delay" scheme. Economic effect of UZS $189.785 \mathrm{mln}$ a year was received due to higher performance of excavators and lower costs of secondary fragmentation in the crushing unit, with ore cost of $3988.75 \mathrm{UZS} / \mathrm{m}^{3}$.

\section{CONCLUSIONS}

Implementation of the explosive destruction method for heterogeneous rocks using splitting charge is substantiated by the fact that the thickness of hard inclusions is determined in the process of drilling blast holes. Between the blast holes, there are shots with depth equal to the depth of strong inclusions, and the width of $0.8 \mathrm{~m}$. Explosive charges are placed at the bottom of the shot, producing a directed cumulative effect. The shot and the blast holes are filled with stemming, the primary and secondary explosive charges are blasted simultaneously. This blast design allows to produce a uniform crushing of heterogeneous rocks due to the usage of blast energy directed into hard inclusions located at the top of the bench in the laminated complex-structured deposits and reduces the weight-volume ratio of explosives.

In the implementation of the developed method of explosive destruction of the mass comprised by heterogeneous rocks using splitting by explosive charges, the expected economic effect is UZS $14.85 \mathrm{mln}$ for $21000 \mathrm{~m}^{3}$ of rock mass.

\section{ACKNOWLEDGEMENTS}

The paper did not originate under any project and no funding was raised.

\section{REFERENCES}

Abdul-Wahab, S., \& Marikar, F. (2012). The Environmental Impact of Gold Mines: Pollution by Heavy Metals. Open Engineering, 2(2), 304-313. https://doi.org/10.2478/s13531-011-0052-3

Afeni, T.B., \& Osasan, S.K. (2009). Assessment of Noise and Ground Vibration Induced During Blasting Operations in an Open Pit Mine - A Case Study on Ewekoro Limestone
Quarry, Nigeria. Mining Science and Technology (China), 19(4), 420-424. https://doi.org/10.1016/s1674-5264(09)60078-8

Dougherty, M.L. (2013). The Global Gold Mining Industry: Materiality, Rent-Seeking, Junior Firms and Canadian Corporate Citizenship. Competition \& Change, 17(4), 339-354. https://doi.org/10.1179/1024529413z.00000000042

Drew, L.J., Berger, B.R., \& Kurbanov, N.K. (1996). Geology and Structural Evolution of the Muruntau Gold Deposit, Kyzylkum Desert, Uzbekistan. Ore Geology Reviews, 11(4), 175-196. https://doi.org/10.1016/0169-1368(95)00033-x

Gasanova, N.Y. (2017). Formation of the Earthquake Database for Evaluation of their Influence on the Slope Stability of Deep Quarries. European Science, (6), 24-26.

Gokhale, B. (2010). Rotary Drilling and Blasting in Large Surface Mines. London: CRC Press, Taylor \& Francis Group. https://doi.org/10.1201/b10972

Kuzu, C., \& Ergin, H. (2005). An Assessment of Environmental Impacts of Quarry-Blasting Operation: A Case Study in Istanbul, Turkey. Environmental Geology, 48(2), 211-217. https://doi.org/10.1007/s00254-005-1291-5

Manoj, K., \& Monjezi, M. (2013). Prediction of Flyrock in Open Pit Blasting Operation using Machine Learning Method. International Journal of Mining Science and Technology, 23(3), 313-316. https://doi.org/10.1016/j.ijmst.2013.05.005

Morelli, R., Creaser, R.A., Seltmann, R., Stuart, F.M., Selby, D., $\&$ Graupner, T. (2007). Age and Source Constraints for the Giant Muruntau Gold Deposit, Uzbekistan, from Coupled Re-Os-He Isotopes in Arsenopyrite. Geology, 35(9), 795-798. https://doi.org/10.1130/g23521a.1

Norov, Y.D., Nasirov, U.F., \& Zairov, Sh.Sh. (2015). Designing of Open and Sustainability Walls. Navoiy: Publishing House "Navoiy".

Norov, Y.D., Shemitov, P.A., Zairov, Sh.Sh., \& Tuxtashev, A.B. (2011). Improvement of Control Methods of Crushing of Rocks by Blast. Buxoro: Publishing House "Buxoro".

Pechenkin, V.G., \& Pechenkin, I.G. (2005). Exfiltrative Mineralization in the Bukantau Ore District (Central Kyzyl Kum Region, Uzbekistan). Lithology and Mineral Resources, 40(5), 462-471.

https://doi.org/10.1007/s10987-005-0043-7

Sekisov, A.G., Shevchenko, Y.S., \& Lavrov, A.Y. (2016). Prospects for Underground Leaching in Gold Mines. Journal of Mining Science, 52(1), 115-120. https://doi.org/10.1134/s1062739116010198

Swenson, J.J., Carter, C.E., Domec, J.C., \& Delgado, C.I. (2011). Gold Mining in the Peruvian Amazon: Global Prices, Deforestation, and Mercury Imports. PloS One, 6(4), e18875. https://doi.org/10.1371/journal.pone.0018875

Wilde, A.R., \& Gilbert, D. (2000). Setting of the giant Muruntau Gold Deposit: Implications for Ore Genesis. Journal of the Virtual Explorer, (1), 3-8. https://doi.org/10.3809/jvirtex.2000.0003

\section{ІНТЕНСИФІКАЦІЯ ТЕХНОЛОГІЧНИХ ПРОЦЕССІВ БУРОПІДРИВНИХ РОБІТ ПРИ РОЗРОБЦІ РОДОВИЩ КИЗИЛКУМСЬКОГО РЕГІОНУ ВІДКРИТИМ СПОСОБОМ}

\section{Ш. Заіров, М. Равшанова, Ш. Карімов}

Мета. Розробка і впровадження способів інтенсифікації процесів буропідривних робіт на кар'єрах Кизилкумського регіону, що дозволяють забезпечити необхідну якість підірваної гірничої маси, можливість управління формою та параметрами розвалу, збереження геологічної структури масиву й скорочення часу підготовчо-відновлювальних робіт.

Методика. Кількісна оцінка ефекту від застосування методу попереднього щілеутворення на кар'єрах Кизилкумського регіону оцінена за допомогою коефіцієнта ефективності застосування контурного підривання, а захисна здатність екрану щілини при контурному підриванні - амплітудним коефіцієнтом, що залежить від ширини екрану щілини, тривалості вибухового імпульсу та фізико-механічних властивостей заповнювача щілини. 
Результати. В результаті проведених теоретичних досліджень отримано залежності для визначення ефективних параметрів контурного підривання з умови сумісності вимоги проростання мережі тріщин між оконтурюючими свердловинами. Захисна здатність екрану щілини істотно залежить від щільності ії заповнювача, тому при розрахунку параметрів контурних зарядів необхідно враховувати розкриття відрізної щілини за рахунок ущільнення прилеглого масиву. Параметри оконтурюючих зарядів повинні вибиратися з урахуванням обмеження зони порушення міжблочних зав'язків відповідно до вимог забезпечення стійкості укосів уступів.

Наукова новизна. Встановлено, що при довготривалому стоянні профіль уступу наближається до профілю межі зони порушень, що дозволяє судити про тривалу стійкість уступу. Розроблено математичну модель, що описує дію вибуху свердловинного заряду вибухової речовини в масиві, на основі якої визначено кінематичні параметри розльоту гірських порід.

Практична значимість. Розроблені ефективні параметри контурного підривання забезпечують створення максимально широкої екрануючої щілини при заданому обмеженні потужності зони порушень міжблочних зв'язків у приукісній частині масиву. При вибуховому розпушуванні гірського масиву з використанням забійки із закріплюючої суміші обсяг пилогазової хмари зменшується на $30-35 \%$ у порівнянні 3 розпушуванням із використанням забійки з бурового дрібняку. Закріплююча суміш впроваджена на кар'єрі Ташкура ДжеройСардарінського родовища фосфоритів.

Ключові слова: відкрита розробка, прикордонна зона, буріння, геологічні умови, підривання

\section{ИНТЕНСИФИКАЦИЯ ТЕХНОЛОГИЧЕСКИХ ПРОЦЕССОВ БУРОВЗРЫВНЫХ РАБОТ ПРИ РАЗРАБОТКЕ МЕСТОРОЖДЕНИЙ КЫЗЫЛКУМСКОГО РЕГИОНА ОТКРЫТЫМ СПОСОБОМ}

\section{Ш. Заиров, М. Равшанова, Ш. Каримов}

Цель. Разработка и внедрение способов интенсификации процессов буровзрывных работ на карьерах Кызылкумского региона, позволяющих обеспечить необходимое качество взорванной горной массы, возможность управления формой и параметрами развала, сохранение геологической структуры массива и сокращение времени подготовительно-восстановительных работ.

Методика. Количественная оценка эффекта от применения метода предварительного щелеобразования на карьерах Кызылкумского региона оценена с помощью коэффициента эффективности применения контурного взрывания, а защитная способность экранирующей щели при контурном взрывании - амплитудным коэффициентом, зависящим от ширины экранирующей щели, длительности взрывного импульса и физико-механических свойств заполнителя щели.

Результаты. В результате проведенных теоретических исследований получены зависимости для определения эффективных параметров контурного взрывания из условия совместимости требования прорастания сети трещин между оконтуривающими скважинами. Защитная способность экранирующей щели существенно зависит от плотности ее заполнителя, поэтому при расчете параметров оконтуривающих зарядов необходимо учитывать раскрытие отрезной щели за счет уплотнения прилегающего массива. Параметры оконтуривающих зарядов должны выбираться с учетом ограничения зоны нарушения межблочных связей в соответствии с требованиями обеспечения устойчивости откосов уступов.

Научная новизна. Установлено, что при долговременном стоянии профиль уступа приближается к профилю границы зоны нарушений, что позволяет судить о длительной устойчивости уступа. Разработана математическая модель, описывающая действие взрыва скважинного заряда взрывного вещества в массиве, на основе которой определены кинематические параметры разлета горных пород.

Практическая значимость. Разработанные эффективные параметры контурного взрывания обеспечивают создание максимально широкой экранирующей щели при заданном ограничении мощности зоны нарушений межблочных связей в приоткосной части массива. При взрывном рыхлении горного массива с использованием забойки из закрепляющей смеси объем пылегазового облака уменьшается на 30 - 35\% по сравнению с рыхлением с использованием забойки из буровой мелочи. Закрепляющая смесь внедрена на карьере Ташкура Джерой-Сардаринского месторождения фосфоритов.

Ключевые слова: открытая разработка, приграничная зона, бурение, геологические условия, взрывание

\section{ARTICLE INFO}

Received: 12 May 2017

Accepted: 16 January 2018

Available online: 22 January 2018

\section{ABOUT AUTHORS}

Sherzod Zairov, Doctor of Technical Sciences, Associate Professor of the Mining Faculty, Navoiy State Mining Institute, 27a Janubiy St, 210100, Navoiy, Uzbekistan. E-mail: sher-z@mail.ru

Mukhabbat Ravshanova, Assistant Professor of the Mining Faculty, Navoiy State Mining Institute, 27a Janubiy St, 210100, Navoiy, Uzbekistan. E-mail: $\underline{m}$ ravshanova@mail.ru

Sherzod Karimov, Student of the Mining Faculty, Navoiy State Mining Institute, 27a Janubiy St, 210100, Navoiy, Uzbekistan. E-mail: karimov20-13@mail.ru 